\title{
Kristološki naglasci govora o Božjem milosrđu u promišljanjima izabranih crkvenih otaca
}

\author{
Andrea Filić" \\ andrea.filic@zg.t-com.hr
}

UDK: UDK: 27-46:27-31]:27-9“01/07“ Izvorni znanstveni rad / Original scientific paper Primljeno: 21. srpnja 2017. Prihvaćeno: 28. rujna 2017.

Polazišno pitanje ovoga članka, nadahnuto tvrdnjama Waltera Kaspera, glasi: Ako milosrde po definiciji u sebi nužno uključuje trpljenje može li se, dok držimo sigurnim da je netrpljivost jedna od bitnih vlastitosti božanske naravi, o njemu uopće govoriti, kako Kasper potiče, kao o temeljnom Božjem svojstvu i odrednici Božje biti? To se pitanje i odgovor na nj obrađuje pod kristološkim vidom i to na temelju promišljanja izabranih crkvenih otaca u čijim djelima pronalazimo govor o Božjem milosrđu u kontekstu specifično kristoloških izlaganja. U prvom se poglavlju ukratko prikazuje Božje milosrdno djelovanje u čitavoj povijesti spasenja i ukazuje na to da se na nj nadovezuje najveći čin i najdivniji iskaz Božjeg milosrda - utjelovljenje, muka i smrt Isusa Krista. U drugom se poglavlju pokazuje kako je ocima riječ milosrde, uporabljena za izricanje motiva i razloga utjelovljenja, muke i smrti Sina Božjega poslužila kao terminus techicus kojim su istodobno očuvali istinu o vječnom Logosu, u sebi netrpljivom, $i$ činjenicu da je taj isti Logos u posljednja vremena postao trpljivim čovjekom te pretrpio muku i smrt na križu. U trećem se poglavlju ukazuje na otačke tekstove u kojima je milosrde utjelovljenja, muke i smrti Sina Božjega prikazano kao najčudesnije djelo i najveće očitovanje moći Božjeg milosrđa, čime se odbacuju sumnje da bi Sin, koji se podložio trpljenju, zbog toga bio subordiniran Ocu. U posljednjem se, četvrtom poglavlju, naslovljenom »Milosrde i hipostatsko sjedinjenje«, usmjeruje na ona mjesta iz otačkih spisa u kojima se milosrđe spominje unutar kristoloških izlaganja koja su na liniji naglaska kalcedonske dogmatske definicije o jednom te istom Isusu Kristu, Sinu Božjemu koji se spoznaje u dvjema naravima sjedinjenima u jednoj osobi ili hipostazi, a koje obje zadržavaju svoje vlastitosti. U zaključku se konstatira da se na početno pitanje može i pozitivno i negativno odgovoriti. Ako se osobu Sina Božjega promatra u njegovoj unutartrinitarnoj

\footnotetext{
* Doc. dr. sc. Andrea Filić, Katolički bogoslovni fakultet Sveučilišta u Zagrebu, Vlaška 38, pp 432, HR-10001 Zagreb.
} 
stvarnosti, onda se ne može reći da je milosrđe temeljno obilježje njegove biti, jer bi to implicitno uključivalo da je božanska narav trpljiva. Ako ga se pak promatra u kontekstu povijesti spasenja, čiji je vrhunac u njegovu postajanju trpljivim čovjekom i u njegovu trpljenju, te ako se tome doda teološka tvrdnja da se snagom hipostatskog sjedinjenja osobi vječne Očeve Riječi može i treba pripisivati vlastitosti ljudske naravi, onda odgovor mora biti pozitivan. Na koncu se, za izraz koji najbolje odgovara otajstvu milosrda očitovana u događaju Isusa Krista, predlaže onaj o Isusu Kristu kao »milosrdu u osobi« ili »uosobljenom milosrdu

Ključne riječi: milosrđe, crkveni oci, kristologija, utjelovljenje.

\section{Uvodne napomene}

Premda je Godina milosrđa ${ }^{1}$ već za nama i premda su se već dobrano utišali glasovi koji su, prema nakani pape Franje, trebali uzburkati srca i savjesti čitave Crkve potičući svakoga pojedinog vjernika da »nitko ne bude ravnodušan pozivu na iskustvo milosrđa $«,{ }^{2}$ bila bi šteta da ta dragocjena tema, kako u teoriji, tako i u praksi, padne u zaborav te ostane zabilježena tek kao naslov jednog od mnogobrojnih jubileja u novijoj crkvenoj povijesti. Stoga se nećemo o njoj libiti ponovno progovoriti, i to iz posebnog kuta, ističući kristološke naglaske Božjeg milosrđa u nauku izabranih crkvenih otaca.

Vjerujemo da su u hrvatskim teološkim, ali i u širim vjerničkim krugovima još uvijek živa sjećanja na mnoge tribine i znanstvene skupove ${ }^{3}$ koji su bili posvećeni temi milosrđa, bilo Božjeg, bilo ljudskog, ili pak obojeg. U tim se prigodama gotovo redovito moglo čuti da se govornici i predavači pozivaju na knjigu Waltera Kaspera: Milosrđe. Temeljni pojam evandelja - ključ kršćanskoga života. ${ }^{4}$ Osobito je bilo isticano Kasperovo pomalo kritičko zapažanje koje iznosi već predgovoru, ${ }^{5}$ a provlači ga i kroz čitavu knjigu, da se u priručnicima

\footnotetext{
${ }^{1}$ Godinu milosrđa proglasio je papa Franjo 11. travnja 2015., na Nedjelju Božjeg milosrđa, bulom Misericordiae vultus - lice milosrđa, a jubilej milosrđa slavio se od svetkovine Bezgrešnog začeća, 8. prosinca 2015., do svetkovine Krista Kralja svega stvorenja, 20. studenog 2016. [usp. Papa FRANJO, Misericordiae vultus - Lice milosrda. Bula najave Izvanrednog jubileja milosrđa (14.04.2015), Zagreb, Kršćanska sadašnjost, 2015, br. 3-5 (dalje: MV)].

${ }^{2}$ MV 19.

${ }^{3}$ Za Zagrebačku nadbiskupiju osobito valja istaknuti 56. teološko-pastoralni tjedan održan u Zagrebu od 26. do 28. siječnja 2016. o temi »Teologija i pastoral Božjeg milosrda«, čiji su radovi objavljeni u: Bogoslovska smotra, 86 (2016) 3, 501-780, te niz od pet tribina »Zajednički vidici« (od siječnja do svibnja 2016.) u organizaciji Ureda za vjeronauk Zagrebačke nadbiskupije, također posvećenih temi milosrđa.

${ }^{4}$ Usp. Walter KASPER, Milosrde. Temeljni pojam evanđelja - ključ kršćanskoga života, Zagreb, Kršćanska sadašnjost, 2015. U spomenutom broju Bogoslovske smotre ta se knjiga spominje više od pedeset puta.

${ }^{5}$ Usp. Kasper, Milosrde..., 9.
} 
dogmatske teologije milosrđe prikazuje samo kao jedno od Božjih svojstava među mnogim drugima, tek nakon svojstava koja proizlaze iz Božje metafizičke biti, ${ }^{6}$ da bi potom istaknuo da milosrđe »moramo označiti kao temeljno Božje svojstvo «, ${ }^{7}$ da je ono »izraz njegova božanskog bića,$^{8}$ ali i $»$ odrednica njegove biti «. ${ }^{9}$ Premda među svojstvima tradicionalno pripisivanima Božjoj metafizičkoj biti izričito ne navodi netrpljivost, ${ }^{10}$ iz daljnjeg je izlaganja očito da i njega u njih uključuje. Na primjer, kada odmah potom tumači problem s kojim se susreće dogmatika govoreći o Božjim svojstvima, ustvrđuje:

»Naime, ako je Bog samo bivstvo, onda iz ove apsolutne punine bivstva proizlazi apsolutna savršenost Božjeg bivstva koja, budući da patnju moramo shvaćati

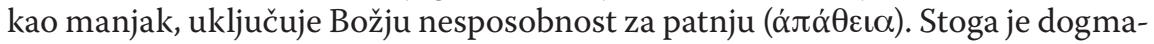
tika zbog svojega metafizičkog polazišta imala poteškoća govoriti o Bogu koji s nama trpi. $\ll^{11}$

$\mathrm{S}$ tom su se poteškoćom bili suočavali crkveni oci nadasve u petom stoljeću, tijekom plodnih, no nerijetko i bolnih rasprava koje su na koncu iznjedrile kalcedonsku kristološku dogmu (451.), pitajući se: Kako spojiti činjenicu da se Sin Božji, vječna Riječ Očeva, netrpljiv u svojoj božanskoj naravi, radi nas i našega spasenja utjelovio i postao trpljivim čovjekom dotle da je podnio muku i nasilnu smrt, najveći mogući iskaz trpljenja? Premda se ovdje nije moguće detaljnije posvetiti tim raspravama, ${ }^{12}$ potrebno je imati u vidu njihov konačan

${ }^{6}$ Usp. osobito isto, 22, 24; usp. i naoko suprotan zaključak Ivana Pavla II.: »Teolozi tvrde da je milosrđe jedan od najvećih pridjevaka Božjih, najveće od njegovih savršenstava.« Velimo naoko, jer brzo nakon ove tvrdnje papa dodaje: »Nije ovdje riječ o savršenstvu neistražive Božje biti u otajstvu njegova božanstva, već o savršenstvu i pridjevku po kojem čovjek, u nutarnjoj istini svoga bivovanja, ulazi u najprisniji i najčišći susret sa živim Bogom «, IVAN PAVAO II., Dives in misericordia - Bogat milosrđem. Enciklika o Božjem milosrđu (30.11.1980), Zagreb, Kršćanska sadašnjost, 1984, br. 13 (dalje: DM).

7 Kasper, Milosrde..., 118; usp. isto, 72-73, 111, 118-119.

${ }^{8}$ Isto, 72.

9 Isto.

${ }^{10}$ Usp. isto, 24, gdje Kasper nabraja ova svojstva: »jednostavnost, beskonačnost, vječnost, sveprisutnost, sveznanje, svemoć i druga «.

${ }^{11}$ Isto, 24. Na to se Kasper navraća i dalje u tekstu (usp. npr. isto, 155, gdje govori o tome da je »tradicionalna školska teologija nijekala Božju sposobnost patnje« te isto, 156-158, gdje ukazuje na to da Biblija ipak dopušta govor o Bogu kao onom koji nije apatičan, nego koji trpi s nama i za nas. Usp. još Raniero CANTALAMESSA, Il volto della misericordia. Piccolo trattato sulla divina e sulla umana misericordia, Milano, Edizioni San Paolo, Cinisello Balsamo, 2015, 17, gdje Cantalamessa upozorava da, kada je u pitanju Božje trpljenje, treba voditi računa o razlici između naravi i osobe u Trojstvu. Kada se veli da u Bogu ne može biti boli, misli se na njegovu narav, jer je Bog kao narav svemoguć i apsolutno savršen. Na istom mjestu konstatira da boli ne može biti ni u unutartrinitarnim odnosima triju božanskih osoba. O boli u Bogu može se govoriti tek kada se misli na odnos svake pojedine božanske osobe sa stvorenim svijetom koji odbija Božju ljubav i svetost, ali ta »bol (...) nije umanjenje ili gubitak životnosti u Bogu, nego samo način kojim se izražava njegova punina života i ljubavi sučelice čovjekovu odbijanju« (isto, 18).

${ }^{12} \mathrm{O}$ tome da je pitanje teopasitizma bilo jedno od važnijih, čak i najvažnijih prijepornih pitanja između antiohijske i aleksandrijske kristologije tijekom kristoloških rasprava u prvoj polovici 
pravovjerni zaključak: Utjelovljeni božanski Logos, Sin Božji, je trpio, ali ne u svojoj božanskoj naravi - ona ostaje netrpljiva. ${ }^{13}$ Prisjetimo li se sada jedne od Augustinovih definicija milosrđa, prema kojoj je ono trpljenje s drugima, za razliku od vlastita trpljenja koje naziva bijedom (»cum ipse patitur, miseria, cum aliis compatitur, misericordia dici solet «), ${ }^{14}$ onda se samo po sebi nameće ovo pitanje: Ako, naime, milosrđe u sebi nužno uključuje trpljenje (pa bilo ono samo zbog drugoga i za drugoga!), može li se, dok držimo sigurnim da je netrpljivost jedna od bitnih vlastitosti božanske naravi, o njemu uopće govoriti, kako Kasper potiče, kao o temeljnom Božjem svojstvu i odrednici Božje biti?

Odgovor na to pitanje potražit ćemo u spisima izabranih crkvenih otaca suzujući svoju obradu na specifično kristološke teme u kojima je, paralelno, riječ o milosrđu. ${ }^{15}$ Pod specifično kristološkim temama ovdje podrazumijevamo one koje se tiču teološke razradbe činjenice da je Bog postao čovjekom i kao čovjek proživio ljudski život sve do smrti na križu. ${ }^{16}$ Predmet našeg istraživanja

V. stoljeća usp. Andrea FILIĆ, Efeška kristološka kontroverzija prema djelima T. J. Šagi-Bunića - od raskola (431.) do sjedinjenja (433.), Zagreb, Kršćanska sadašnjost, 2015, osobito 162-164, 174-184, 245-250, 378-380, 410-412, 450-451. U pripadajućim bilješkama čitatelj može pronaći i brojne izvore o tom pitanju, kako Šagi-Bunićeve, tako i one drugih suvremenih svjetskih autora.

${ }^{13}$ Premda u samoj kalcedonskoj definiciji u strogom smislu to nije definirano, takve se izjave nalaze u trima spisima koje je svečano odobrio Kalcedonski sabor (o njihovu odobravanju i prihvaćanju na drugom zasjedanju 10. listopada 451. i četvrtom zasjedanju 17. listopada 451. vidi u: Pierre-Thomas CAMELOT, Éphèse et Chalcédoine. 432 et 451. Histoire des conciles œесuméniques, Paris, Fayard, $\left.{ }^{2} 2006,126-127,130-131\right)$. Usp. Ćiril ALEKSANDRIJSKI, Ćirilovo pismo Nestoriju, u: Ćiril ALEKSANDRIJSKI, Utjelovljenje Jedinorodenca - jedan Krist, prijevod, uvod i bilješke Marijan Mandac, Makarska, Služba Božja, 2001, 303: „Nije Božja Riječ trpjela u vlastitoj naravi udarce ili otvore čavala, kao i sve druge rane, jer božanstvo kao netjelesno ne podliježe trpljenju. Budući da je navedeno pretrpjelo tijelo što postade Njezinim vlastitim tijelom, opet kažemo da je Ona trpjela za nas jer je u tijelu što je trpjelo bila Ona koja ne može trpjeti«; Ćiril ALEKSANDRIJSKI, Pismo Ivanu Antiohijskom, u: Ćiril Aleksandrijski, Utjelovljenje Jedinorodenca - jedan Krist..., 328: »Osim toga, svi ispovijedamo da Božja Riječ ne može trpjeti. Ipak, sama premudro ravnajući otajstvom, patnje što su se dogodile njezinome tijelu, vidi se, pripisuje sebi. Stoga i veli premudri Petar: 'Krist je, dakle, trpio za nas tijelom' (1 Pt 4, 1), a ne naravlju neizrecivoga božanstva«; Epistula Papae Leonis ad Flavianum ep. Constatinopolitanum de Eutyche, u: Josepho ALBERIGO i dr. (ur.), Conciliorum oecumenicorum decreta, Istituto per le scienze religiose, Bologna, ${ }^{3} 1973,80$, gdje papa Leon Veliki govoreći o jedinstvu naravi koje treba shvatiti u dvjema naravima zaključuje da treba reći da je Sin Božji bio raspet i pokopan, ali da to nije pretpio u svojem božanstvu po kojem je istovječan i istobitan Ocu, nego u slabosti ljudske naravi.

${ }^{14}$ AUGUSTINE, Confessions, I, Oxford,1992,23, https://books.google.hr/books?id=Y3wWAQAA MAAJ\&printsec $=$ frontcover\&hl $\# \mathrm{v}=$ onepage\&q\&f=false (21.07.2017). Usp. i hrvatski prijevod u: Aurelije AUGUSTIN, Ispovijesti, Zagreb, Kršćanska sadašnjost, ${ }^{4} 1987,46:$ : Kad sami trpimo, obično se to zove bijeda, a kad s drugima trpimo, samilost."

${ }^{15}$ Najviše takvih mjesta pronašli smo kod Augustina i Leona Velikog. U drugom dijelu rada gotovo ćemo se isključivo na njih pozivati. Ipak, zbog toga što u prvom dijelu svoje izlaganje temeljimo i na promišljanjima drugih crkvenih otaca, smatramo da ne bi bilo primjereno da smo se i u naslovu ograničili na dvojicu spomenutih autora.

${ }^{16}$ Ovdje se nećemo moći baviti mnogobrojnim otačkim tumačenjima pojedinih novozavjetnih primjera Isusova milosrđa i njegova iskazivanja sućuti prema umornima, iscrpljenima, grešnicima, isključenima, bolesnima, opsjednutima, izgubljenima i odbjeglima, jednom riječju, 
dakle pripada dogmatskoj teologiji za koju je Kasper uvidio da se prema Božjem milosrđu dugi niz godina maćehinski ophodila. ${ }^{17}$ Ovim radom, dozivajući u sjećanje promišljanja crkvenih otaca o Božjem milosrđu iznesena u kontekstu kristološke problematike, želimo učiniti malen korak u prilog ispravljanju toga maćehinskog odnosa. Na to nas, uostalom, potiču i riječi pape Franje koje stoje na početku Bule najave Izvanrednog jubileja milosrda:

»Isus Krist je lice Očevog milosrđa. U ovim riječima može se dobro sažeti tajna kršćanske vjere. Milosrde je postalo živo i vidljivo u Isusu iz Nazareta, dosežući u njemu svoj vrhunac. ${ }^{18}$

\section{Utjelovljenje Sina Božjega u kontekstu govora o Božjem milosrdnom djelovanju u čitavoj povijesti spasenja}

$\mathrm{Na}$ samom početku vrijedno je iznijeti nekoliko napomena koje se ne tiču strogo kristoloških naglasaka Božjeg milosrđa, ali su, smatramo, bitne za njihovo razumijevanje. Potrebno je barem u, slikari bi rekli, kroki tehnici prikazati neke elemente otačkoga govora o Božjem milosrđu općenito.

Ponajprije, valja konstatirati da su pojedini oci doista govorili o milosrđu kao onome što je Bogu unutarnje, vlastito. Tako na primjer kod Ireneja iz Liona pronalazimo ovaj izričaj: »Smilovati se jest vlastitost Boga koji ima moć spasiti svojim milosrđem. ${ }^{19}$ Ćiril Aleksandrijski čak veli da je ono atribut božanske naravi te poziva svoje čitatelje da to dobro zapamte, ${ }^{20}$ a slično će, da je milosrđe

svima koji na bilo koji način trpe. O tome više vidi u: PONTIFICIO CONSIGLIO PER LA PROMOZIONE DELla NUOVA EVANGELIZZAZIONE, La Misericordia nei Padri della Chiesa, San Paolo, Milano, 2015, 22-38, 64-75, 85-91, 116-118; Kasper, Milosrde..., 83-102; također vidi knjigu Raniera Cantalamesse, Il volto della misericordia...

${ }^{17}$ Usp. Kasper, Milosrđe..., 9, 24. Za to se pitanje, kako se dade iščitati iz njegova predgovora, Kasper primarno zainteresirao pripremajući predavanje o Božjem milosrđu za potrebe duhovnih vježbi te se i kasnije njime intenzivno bavio. Kroz istraživanje tekstova o Božjem milosrđu uvidio je da je, za razliku od kršćanske duhovnosti i mistike te pastoralne teologije, sustavna teologija tu temu potiskivala i zaobilazila. Svojom je knjigom želio ispraviti taj nedostatak te ujedno ukazati na potrebu povezivanja akademske i duhovne teologije (usp. isto, 9).

${ }^{18}$ MV 1.

${ }^{19}$ Usp. Irénée de LYON, Démonstration de la prédication apostolique, Les Éditions du Cerf, Paris, 2011, 60 (djelo navodimo prema brojevima, a ne stranicama; dalje: Dem.). U latinskom prijevodu koji je načinio Adelin Rousseau dolazi do izražaja igra riječima smilovati se (misereri) i milosrđe (misericordia): »misereri proprium est Dei illius, qui et per misericordiam salvare potest « (isto, 170). Na taj tekst upućuje i Kasper, Milosrđe..., 111, koji iz navedenog citata iščitava da je prema Ireneju »milosrđe posebno Božje svojstvo« (isto).

${ }^{20}$ Usp. Cyril of ALEXANDRIA, Commentary on Luke (1859) Sermons 27-38. (Luke 6:20-7:28) pp. 102-148, Sermon XXIX, www.tertullian.org/fathers/cyril_on_luke_03_sermons_26_38. htm\#SERMON XXIX (21.07.2017). Ćiril te riječi donosi između govora o Božjoj sućuti/ smilovanju i doslovnoga citata iz Lk 3, 36 (»Budite milosrdni kao što je vaš Otac milosrdan«). Iz konteksta se dade zaključiti da poistovjećuje sućut/smilovanje i milosrđe kao jedan te isti 
vlastiti atribut božanstva, ustvrditi i Gregorije Nisenski. ${ }^{21}$ Ipak, izričaji koji su na liniji navedenih primjera uvelike su rjeđi od onih u kojima se ističe Božje milosrdno djelovanje u povijesti spasenja. Tekstovi crkvenih otaca, osobito kada tumače mjesta iz Starog i Novog zavjeta kroz koja prosijeva Božja milosrdna crta, obiluju takvim govorom. Božje milosrđe oci pronalaze u svim etapama povijesti spasenja. Tako je već samo stvaranje bilo shvaćano kao izraz Božjeg milosrđa, jer je Bog stvorio čovjeka kao svoju sliku, da bi u njega položio svoja dobra i dao mu dioništvo u svojem životu. ${ }^{22}$ Nakon što je čovjek sagriješivši odbacio Božju ponudu, povijest spasenja zapravo postaje povijest neprestanih Božjih milosrdnih izlazaka iz sebe samoga ususret palom i grešnom čovječanstvu, kroz koje mu uvijek iznova pokazuje svoju neizmjernu ljubav i dobrotu.

Božje milosrđe nadasve dolazi do izražaja u Božjoj pedagogiji prema grešnome čovjeku, u njegovoj strpljivosti, opraštanju i otvaranju uvijek novih prilika za približavanje onoj izvornoj nakani koju je, stvarajući ga, s njime imao. ${ }^{23}$ Usto se Božje milosrdno srce sažaljuje nad ljudskom bijedom. ${ }^{24}$ Origen će u vezi s

atribut božanske naravi. Na gore navedenu izjavu aleksandrijskog biskupa (Komentar na Luku, Homilija 29) dvaput upućuje Papinsko vijeće za promicanje nove evangelizacije (usp. Pontificio consiglio per la promozione della nuova evangelizzazione, La Misericordia nei Padri della Chiesa..., 29, 114-115).

${ }^{21}$ Usp. Gregorius NYSSENUS, De beatitudinibus, Oratio V, u: Jacques Paul MIGNE (ur.), Patrologiae cursus completus. Series Graeca, Paris, 1857.-1866., 46, 1250 (dalje: PG). O tome Gregorije govori u kontekstu pozivanja ljudi na milosrđe.

${ }^{22}$ Usp. npr. Dem., 8; Irénée de LYON, Contre les hérésies. Dénonciation et réfutation de la gnose au nom menteur, Paris, Les Éditions du Cerf, 2007, I, 10, 3 (djelo navodimo prema brojevima, a ne stranicama; dalje: AH); ATHANASIUS, Oratio de Incarnatione Verbi, 3; 11, u: PG, 25, 101-102; 113-116; Gregorius NYSSENUS, De hominis opificio, caput XVI, u: PG, 44, 181-186; Augustin, Ispovijesti..., 13; Aurelius AUGUSTINUS, Sermo 254. In diebus paschalibus, 1, www. augustinus.it/latino/discorsi/discorso_352_testo.htm (21.07.2017). Prijevod Augustinovih govora na hrvatski vidi u: AUGUSTIN, Govori - 1, prijevod, uvod i bilješke Marijan Mandac, Makarska, Služba Božja, 1990; AUGUSTIN, Govori - 2, prijevod, uvod i bilješke Marijan Mandac, Makarska, Služba Božja, 1993.

${ }^{23}$ Božju milosrdnu pedagogiju oci predočuju na različite načine. Usp. npr. Poslanica Diognetu, u: Tomislav Janko ŠAGI-BUNIĆ, Povijest kršćanske literature, I, Zagreb, Kršćanska sadašnjost, 1976, 288-289, gdje je riječ o tome da je Bog iz pedagoških razloga dopustio da neko vrijeme ostanemo prepušteni svojoj volji, tolerirajući naše grijehe da bi ih na koncu u svojem milosrđu uzeo na sebe, dajući vlastitoga Sina kao otkupninu za nas. Na sličnom je tragu i Irenejevo pozivanje na Rim 11, 32, prema kojem je Bog sve zatvorio u neposlušnost kako bi svima iskazao milosrde (usp. AH, I, 30, 3; III, 20, 2) te je dopustio da čovjek prođe kroz sve situacije te upozna smrt (usp. AH, III, 20, 2). Lionski biskup, usko vezano uz govor o milosrdnom Bogu, progovara i o Božjoj strpljivosti (usp. AH, I, 10, 3) i o tome kako Bog ljude nije lišio dobroga savjeta (usp. AH, IV, 17, 2; također usp. AH, IV, 37, 1). I Jeronim ističe da je Bog strpljiv i milosrdan, da dugo čeka naše obraćenje, blag je i strpljiv sa zlima (usp. Eusebius HIERONYMUS, Commentariorum in Joelem prophetam, II, 191, u: Jacques Paul MIGNE [ur.], Patrologiae cursus completus. Series Latina, Paris, 1857.-1866., 25, 967 [dalje: PL]). Augustin pak govori da je Božje milosrđe na djelu i kada dopušta da čovjek upadne u kušnje; štoviše, tada milosrđe naziva slatkim [usp. Augustinus HIPPONENSIS, In Psalmum 68 ennaratio 2, 1, www. augustinus.it/latino/esposizioni_salmi/esposizione_salmo_086_testo.htm (21.07.2017)].

${ }^{24} \mathrm{Na}$ tom tragu veoma zanimljivo izlaganje o Božjem milosrđu prema Adamu koji je sagriješio, vidi u AH, III, 23, 3. Ono se očitovalo u tome što je Bog Adama, shvativši njegov čin zaodijevanja 
time progovoriti i o svojevrsnoj Očevoj patnji zbog njegova milosrđa i ljubavi te, $u$ tome kontekstu, smjelo odstupiti od ustaljenih načina promišljanja o Bogu kazavši da »sam Otac nije netrpljiv« ${ }^{25}$ Koliko god ta teza izazovno zvuči, u njoj, valja primijetiti, nije ustvrđena trpljivost božanske naravi, nego je riječ o osobi Oca. Oca koji je u svojem milosrđu i smilovanju poslao svojega Sina kako bi se u njemu ostvarilo zajedništvo Boga i čovjeka. ${ }^{26}$ Upravo se na tu trajnu Božju milosrdnu prisutnost i djelovanje u Starom zavjetu usko nadovezuje utjelovljenje Sina Božjega ${ }^{27}$ - taj, kao što ćemo vidjeti, za oce najveći i najčudesniji čin Božjega milosrđa.

Leon Veliki, u svojim božićnim propovijedima, često ukazuje na činjenicu da je Božje milosrđe, na osobit način očitovano u utjelovljenju Isusa Krista, pripravljeno »od početka svijeta $\aleph^{28} \mathrm{i} »$ prije vjekova $\ll^{29}$ te je djelatno u čitavoj povijesti spasenja. Riječ je, prema Leonu, o jednom te istom sredstvu univerzalnog spasenja ustanovljenom od postanka svijeta, a ne o novoj odluci ili zakašnjelom smilovanju - »jer milost Božja, kojom su se oduvijek opravdavali svi sveti, porasla je, a ne započela Kristovim rođenjem «. ${ }^{30}$ Taj porast obilja Božje dobrote, koja se oduvijek na različite načine očitovala ljudskom rodu, dogodio se u posljednja vremena, kada je u Kristu grešnicima sišlo milosrđe, tj. kada je Logos, suvječan i jednak Ocu u božanskoj naravi uzeo ljudsku narav te se isti, Bog rođen od Boga, rodio kao čovjek od čovjeka. ${ }^{31}$

smokvinim agresivim lišćem kao čin pokajanja, milosrdno obukao u tuniku od kože. Prema Ireneju je Bog mrzio onoga koji je zaveo čovjeka, a za zavedenog je čovjeka malo pomalo osjećao sućut, smilovanje.

${ }^{25}$ Usp. ORIGENES, In Ezechielem. Homilia VI, 6, u: PG, 13, 714-715. Komentar toga teksta, u kojem je konstatirano da je Origen inače zastupao dogmu o božanskoj netrpljivosti, no u slučaju milosrđa, kako se čini, posve suprotno, vidi u: Pontificio consiglio per la promozione della nuova evangelizzazione, La Misericordia nei Padri della Chiesa..., 15.

${ }^{26}$ Usp. Dem., 37.

${ }^{27}$ Usp. npr. tumačenje Prokla Carigradskog u kojem, polazeći od Sinovljeva odnosa prema Ocu, preko Sinovljeva sudjelovanja u stvaranju, dolazi do govora o njemu kao Milosrdniku te zaključuje: »Nije dakle prezreo narav, dugo potlačenu, onaj koji je po naravi kralj; nije dopustio milosrdni Bog da dokraja ostane obvezana đavlu. Nego: dođe onaj koji je vijekom prisutan i proli kao otkupninu za nas vlastitu krv: preda smrti, kao zamjenu za rod, tijelo što ga uze od Djevice. (...) Jer da nije mene obukao, ne bi mene niti spasio!«, Proklo CARIGRADSKI, Homilija o Bogorodici, u: Tomislav Janko ŠAGI-BUNIĆ, Kristologija Prokla Carigradskog, Zagreb, Kršćanska sadašnjost, 2009, 354-355. Ovdje je dobro dodatno naglasiti činjenicu da je riječ o onome koji je »vijekom prisutan «.

${ }^{28}$ Leo MAGNUS, Sermo XXIII. In Nativitate Domini III, 2, u: PG, 54, 202; Leo MAGNUS, Sermo XXII. In Nativitate Domini II, 1, u: PL, 54, 194-195. Leonove govore prevedene na hrvatski jezik također vidi u marno pripravljenom djelu: Leon VELIKI, Govori, prijevod, uvod i bilješke Marijan Mandac, Makarska, Služba Božja, 1993.

${ }^{29}$ Leo MAGNUS, Sermo XXX. In Nativitate Domini X, 6, u: PL, 54, 233.

${ }^{30}$ Leo MAGNUS, Sermo XXIII. In Nativitate Domini III, 2, u: PG, 54, 202.

${ }^{31}$ Usp. Leo MAGNUS, Sermo XXIV. In Nativitate Domini IV, 1, u: PL, 54, 203-204. 


\section{Božje milosrde - motiv i razlog utjelovljenja, muke i smrti Sina Božjega}

S idejom iskazanom u potonjim riječima Leona Velikog o utjelovljenju kao silasku milosrđa, u kojoj je snažno naglašeno da se time što je Logos postao čovjekom ne događa nikakva promjena u njegovoj božanskoj naravi nego, štoviše, ostaje isti, susretat ćemo se tijekom čitava našeg izlaganja. Uočljivo je da je mnogim ocima riječ milosrđe služila kao sretno iznašašće kojim su uspjeli istodobno zadržati istinu o netrpljivosti i nepromjenjivosti božanske naravi Sina Božjega i istinu da je taj isti Sin Božji, ostajući u svojoj božanskoj naravi ono što je oduvijek bio, uzeo ljudsku narav i postao ono što prije nije bio, trpljivim čovjekom. Pritom rado ističu da je milosrđe motiv utjelovljenja Sina Božjega. Origen jasno govori da je utjelovljenje posljedica Spasiteljeva ganuća milosrđem: Spasitelj je, vidjevši da je čovjek, koji je bio stvoren na njegovu sličnost, obukao sliku zla, ganut milosrđem, uzeo sliku čovjeka. ${ }^{32} \mathrm{U}$ vezi s time kod njega pronalazimo još jednu zanimljivu i, opet, smjelu ideju. Tumačeći kako je Spasitelj sišao na zemlju zbog smilovanja/milosrđa prema ljudskom rodu, veli da je on prvo patio, a potom sišao i bio viđen. Sinovljeva patnja, koju poistovjećuje s ljubavlju, prethodi dakle, prema Origenu, i utjelovljenju i križu. ${ }^{33}$ Atanazije, premda u svojem zaključku neće otići tako daleko kao Origen, također jasno progovara o smilovanju i milosrđu kao motivu utjelovljenja, pri čemu, unatoč Sinovljevu silasku u propadljivost, ostaje očuvana njegova nepropadljivost. Prema njemu je, naime, bestjelesni, nepropadljivi i nematerijalni Bog Logos, ostajući kod Oca došao u našu stvarnost. Budući da su svi ljudi bili pod kaznom smrti, on se smilovao našem rodu i iskazao milosrđe našoj slabosti te je sišao u našu propadljivost, uzevši naše tijelo. ${ }^{34}$ Najsažetiji i, kako nam se doima, najzvučniji primjer vezan uz tu problematiku pronalazimo u Homiliji o Bogorodici Prokla Carigradskog:

»Onaj koji je po naravi netrpljiv, postade po milosrđu podvržen mnogim patnjama. Nije Krist po napredovanju postao Bog - ni govora! - nego jest Bog i po milosrđu je postao čovjek.. ${ }^{35}$

\footnotetext{
${ }^{32}$ Usp. ORIGENES, In Genesim Homilia I, 13, u: PG, 12, 157.

${ }^{33}$ Usp. ORIGENES, In Ezechielem. Homilia VI, 6, u: PG, 13, 714. Usp. i sličnu ideju Paulina iz Nole, koji doduše ne spominje milosrđe, o tome kako Krist od početka vjekova pati u svima svojima. Nakon što navodi primjere kako je Krist trpio u Abelu, Noi, Abrahamu, Izaku, Jakovu, Josipu, Mojsiju, prorocima, apostolima i mučenicima, to isto trpljenje, »radi nas i u nama«, proteže i na sva daljna vremena. Usp. Paulinus NOLANUS, Epistola XXXVIII, 3, u: PL, 61, 359. O tome da je Kristovo trpljenje vrhunski dokaz Božjeg milosrđa, ali da u Bogu i prije utjelovljenja postoji patnja ljubavi usp. i Cantalamessa, Il volto della misericordia..., 85.

${ }^{34}$ Usp. ATHANASIUS, Oratio de Incarnatione Verbi, 8, u: PG, 25, 109-110.

${ }^{35}$ Proklo Carigradski, Homilija o Bogorodici..., 353. U doktorskoj disertaciji, napisanoj prije ovoga prijevoda, Sagi-Bunić donosi sljedeću formulaciju: »Onaj dakle po naravi netrpljiv postao je iz milosrđa mnogotrpljiv« (Šagi-Bunić, Kristologija Prokla Carigradskog..., 38; usp. isto, 143144). Za naš je rad zanimljivo njegovo tumačenje Proklovih riječi. U više navrata (usp. isto, 102-
} 
Malo dalje u istoj propovijedi jasno daje do znanja da Sinovljevo milosrđe ne unosi nikakvu promjenu u njegovu odnosu prema Ocu:

»Jedan je jedini iz Djevice rođeni Bog i čovjek. [...] Ukoliko je, naime, Sin, ostaje u nepromjenljivosti prema Ocu; ukoliko je Stvoritelj, posjeduje moć koja za to treba; ukoliko je Milosrdnik, očitovao je nenadmašivost u suosjećanju pred licem javnosti... $\aleph^{36}$

Po milosrđu, zbog i radi njega, Bog dakle postaje čovjekom i podložen mnogim patnjama. Pod tim pak patnjama valja podrazumijevati sve događaje iz ekonomije spasenja očitovane u utjelovljenom Sinu Božjemu. To veoma lijepo sažima Bazilije Veliki koji, nakon izlaganja o razlici Kristovih imena - onih koja »objavljuju jedino njegovo božanstvo i veličinu« te se njima iskazuje ono dostojanstvo koje mu je vlastito i onih koja »označuju (...) raznoliko djelovanje kojim potrebnima, već kako kome treba, pritječe u pomoć iz milosrđa prema svom vlastitom stvoru« te je njima iskazana njegova milost prema nama - poziva:

»Ne držimo, dakle, povijest spasenja po Sinu prisilnom poput robovske podložnosti, već dobrovoljnom brigom učinjenom iz dobrote i milosrđa, po volji Boga Oca, za vlastito stvorenje. « ${ }^{37}$

$\mathrm{S}$ jednakim ciljem kojim Bazilije milosrđe kontraponira prisili - kako bi istaknuo dobrovoljnost Sinovljeve ekonomije - Augustin i Leon Veliki ga suprotstavljaju nužnosti. ${ }^{38}$ Augustin tako jasno razlikuje volju Gospodinova milosrđa od onoga stanja koje je Gospodinu »nužno«, koje pripada njegovoj božanskoj naravi:

103, 143-144, 163) ističe činjenicu da je u Proklovoj izjavi jasno istaknuto da je Logos po svojoj »naravnoj nužnosti«, po onome što ga »nužno konstituira«, što mu »pripada nužno«, Bog i netrpljiv. Iz izričaja da je taj isti Logos postao čovjekom i »mnogotrpljivim« »po milosrđu«, tj. »iz milosrđa«, Šagi-Bunić iščitava da je »inkarnacija bila slobodan čin božanskog Logosa«, da se tiče njegova »slobodovoljnog određenja «, »slobodne volje«. Već se kod Prokla, kada njegovoj tvrdnji dademo smisao Šagi-Bunićeva tumačenja prema kojem riječi »iz milosrđa« označavaju motiv inkarnacije i isključuju svaku nužnost utjelovljenja, nazire zaključak s kojim ćemo se uskoro susresti kod Augustina i Leona Velikog, koji izravno povezuju milosrđe i nenužnost inkarnacije. Još neka druga mjesta iz Proklovih spisa u kojima carigradski biskup rabi riječ milosrđe u gore opisanom smislu vidi u: isto, 38, 110, 142, 151.

${ }^{36}$ Proklo Carigradski, Homilija o Bogorodici..., 354-355.

${ }^{37}$ Bazilije VELIKI, Duh Sveti, prijevod, uvod i bilješke Marijan Mandac, Makarska, Služba Božja, 1977, 76-78. O Kristovu imenu kao onome koje je koje je vezano uz utjelovljenje kao čin rasporedbe, širenja milosrđa, usp. Aurelius AUGUSTINUS, Epistola 238, 3.18, www. augustinus.it/latino/lettere/lettera_246_testo.htm (21.07.2017).

${ }^{38}$ Ovdje je zanimljivo barem usputno primijetiti da Cantalamessa, prije negoli će se posvetiti milosrđu očitovanom u povijesti spasenja, govori o unutartrojstvenoj ljubavi kao svojevrsnoj nužnosti: »Ta ljubav koja je u Trojstvu - i koja konstituira Trojstvo - narav je (...), a ne milost, ljubav je, a ne milosrđe. To što Otac ljubi Sina nije milost ili koncesija, ona je, u nekom smislu, nužnost; Otac ima potrebu ljubiti da bi postojao kao Otac. To što Sin ljubi Oca, to nije koncesija ili milost; to je nutarnja, i slobodna nužnost; on ima potrebu biti voljen i voljeti da bi bio Sin. Otac rađa Sina u Duhu Svetome, tj. ljubeći ga; Otac i Sin nadišu Duha Svetoga ljubeći se«, Cantalamessa, Il volto della misericordia..., 11-12. 
»Ove kretnje ljudske slabosti, kao i tijelo ljudske slabosti i smrt ljudskoga tijela Gospodin Isus je uzeo ne iz nužnosti svojega stanja, nego iz volje svojega smilovanja. ${ }^{39}$

I rimski biskup ističe da Jedinorođenac nije podnio trpljenje zbog nužnosti, nego zbog milosrđa. ${ }^{40}$ Čini se da su na istome tragu i riječi Teodora Mopsuestijskog koji, nadasve osjetljiv za razliku Kristovih imena, također navodi milosrđe kao motiv utjelovljenja:

»Dakle, s punim pravom, kazali su oni (naši oci) ponajprije ‘jedini' i potom 'prvorođenac', jer je dolikovalo da nam najprije ukažu tko je taj koji je u obličju Božjem, a po svome je milosrđu uzeo (taj jedan) našu narav i da nam potom govore o obličju sluge koje je uzeo za naše spasenje. (...) Čuvajući red koji se nameće, oni su najprije poučili o božanskoj naravi, koja se po milosrđu spustila nama i obukla se u jednoga čovjeka, a potom o ljudskoj preuzetoj po milosti...« ${ }^{41}$

$\mathrm{Na}$ koncu, dodajmo i to da je ono isto utjelovljenje koje je, kada ga se promatra iz perspektive božanstva u sebi, bilo posvema nenužno, na izvjestan način bilo nužno kada ga se promatra iz perspektive božanstva okrenuta nama i našemu spasenju. Kao primjer za potvrdu te tvrdnje, u kojoj, što je za nas važno, pronalazimo i spomen neizrecivog nauma Božjeg milosrđa ostvarena u otkupiteljskoj žrtvi Sina Božjega, možemo i opet navesti Leona Velikog koji govori o tome da se Sin Božji rodio, tj. uzeo smrtno tijelo, kako bi mogao biti raspet i podnijeti trpljenje za nas. ${ }^{42}$

Sažmimo, prije prelaska na iduće poglavlje, zaključke navedenih otačkih promišljanja. Govor o milosrđu kao motivu utjelovljenja, muke i smrti Sina Božjega crkvenim je ocima činio svojevrsnu sponu između vječnog i netrpljivog Logosa i Logosa koji se, postavši čovjekom podvrgao trpljenju - bilo da je ono shvaćeno doslovno, kao trpljenje na križu i u smrti, bilo da je riječ o trpljenju shvaćenom kao podvrgnutost promjenjivosti koju sa sobom nužno nosi rođenje i život u obličju čovjeka. Naglaskom na činjenici da je čin utjelovljenja i trpljenja posve slobodnovoljni čin vječnoga Logosa, motiviran isključivo njegovom milosrdnom ljubavlju koja se smilovala ljudskoj bijedi, isključili su svaku opasnost

\footnotetext{
${ }^{39}$ Aurelius AUGUSTINUS, In Psalmum 87 ennaratio, 3, www.augustinus.it/latino/esposizioni salmi/index2.htm (17.06.2017). Vidi i Aurelius AUGUSTINUS, Sermo 196. In Natali Domini, 3, www.augustinus.it/latino/discorsi/discorso_249_testo.htm (21.07.2017) gdje hiponski biskup veli da je Gospodin zbog nas htio postati čovjekom, da milosrde ne izgubi vrijednost.

${ }^{40}$ Usp. Leo MAGNUS, Sermo LXIX. De Passione Domini XVIII, 3, u: PL, 54, 377.

${ }^{41}$ Teodor MOPSUESTIJSKI, Katehetske homilije, predgovor, uvod i prijevod Tomislav Zdenko Tenšek, Zagreb, Kršćanska sadašnjost, 2004, 21. Teodor Mopsuestijski bio je predstavnik antiohijske kristologije, koja je među ostalim snažno isticala oprečnost pojmova »po naravi« $\mathrm{i}$ »po milosti«, odnosno »po naravi« i po »slobodnoj volji«. O tome više vidi u: Filić, Efeška kristološka kontroverzija..., 190-191, bilj. 240.

${ }^{42}$ Usp. Leo MAGNUS, Sermo XLVIII. De Quadragesima X, 1, u: PL, 54, 298. Usp. i Leo MAGNUS, Sermo LVIII. De Passione Domini VII, 4, u: PL, 54, 335-336, gdje Leon također povezuje činjenicu da je Sin Božji uzeo pravog i čitavog čovjeka i činjenicu da se zbog milosrđa podložio patnjama naše smrtnosti da bi ih iscijelio.
} 
govora o utjelovljenju i trpljenju kao da bi oni bili nužni. Kada bi, naime, oni bili nužni, to bi uključno podrazumijevalo da je i Logos sam u sebi na neki način podložan promjenama i trpljenju, što bi pak vodilo u herezu po kojoj bi Logos bio manji od Oca. Rješenje prema kojem je motiv i razlog utjelovljenja milosrdna volja Boga Logosa koji, postajući ono što dotad nije bio u sebi ostaje ono što je oduvijek bio na najbolji mogući način otklanja svaku mogućnost takvih heretičkih tumačenja.

\section{Utjelovljenje, muka i smrt Sina Božjega - najčudesnije djelo $i$ očitovanje moći Božjeg milosrđa}

Započnimo i ovaj odlomak osvrtom na kraj prethodnoga i to tako da dovedemo u pitanje sigurnost ondje iznesene tvrdnje. Naime, u nekim je tekstovima crkvenih otaca, čija je kristološka ortodoksija neupitna, moguće pronaći izričaje koji na prvi pogled mogu ostaviti dojam da je, upravo zbog svojeg milosrđa očitovana u njegovu postajanju čovjekom, Sin ipak na neki način subordiniran u odnosu na Oca. Tako, npr., Augustin Isusu stavlja u usta ovaj nastavak njegovih riječi »Otac je veći od mene: Od mene je veći po tome što sam čovjek, jednak sam s njime po tome što sam Bog.« Potom dodaje: »Jednak po naravi, veći po Sinovljevu milosrđu. « ${ }^{43}$ Isto tumačenje, također s podsjećanjem na Gospodinovo milosrđe, pronalazimo i na drugom mjestu gdje veli da je jedinorođeni Sin Božji, koji je radi našega spasenja, kada je došla punina vremena, uzeo obličje sluge, po tome obličju rekao da je Otac veći od njega, dok je po Božjem obličju rekao da su on i Otac jedno. ${ }^{44}$

Na sličnom su tragu i riječi Leona Velikog koji čak kaže da je Sin Božji, uzevši ljudsku narav i iskazujući milosrđe bijednima, postao manji ne samo od Oca, nego i od samoga sebe. Dakako da usto pažljivo dodaje da je manji samo po našem, a ne i po onome što mu je vlastito. ${ }^{45}$ Također, opet u kontekstu govora o Božjem milosrđu, kroz brojne primjere snažno naglašava da je riječ o istome koji, ostajući ono što jest u svojoj naravi, uzima ono što je vlastito ljudskoj naravi. $^{46}$

\footnotetext{
${ }^{43}$ Aurelius AUGUSTINUS, Sermo 264, De ascensione Domini, 4, www.augustinus.it/latino/ discorsi/discorso_369_testo.htm (21.07.2017). Usp. i Aurelius AUGUSTINUS, Sermo 252, In diebus Paschalibus, 1, www.augustinus.it/latino/discorsi/discorso_349_testo.htm (21.07.2017) gdje autor veli da u Svetim pismima Gospodin pokazuje i uzvišenost svojega božanstva i milosrđe svojega čovještva. Također usp. Aurelius AUGUSTINUS, Sermo 264, De ascensione Domini, 3, www.augustinus.it/latino/discorsi/discorso_369_testo.htm (21.07.2017).

${ }^{44}$ Usp. Aurelius AUGUSTINUS, Epistola 238, 2.10; www.augustinus.it/latino/lettere/lettera_246_ testo.htm (21.07.2017).

${ }^{45}$ Usp. Leo MAGNUS, Sermo XXV. In Nativitate Domini V, 2, u: PL, 54, 209.

${ }^{46}$ Usp. Leo MAGNUS, Sermo XXX. In Nativitate Domini X, 5-6, u: PL, 54, 233-234, gdje Leon, tumačeći kako nas odluka Božeg milosrđa preobražava za nevinost i život i razrješuje naše okove, govori o istome koji je u obličju Božjem i koji je uzeo obličje sluge, o istome koji je
} 
Navedeni tekstovi, kada ih se pažljivo i u cijelosti promotri, ne daju nikakva povoda da bismo gore navedenu hipotetsku bojazan mogli ozbiljno uzeti. U svima je naime više nego očit zaključak koji smo iznijeli i u prošlom poglavlju: Sin, unatoč tome što iz milosrđa uzima ljudsku narav, u božanskoj naravi ostaje jednak Ocu.

Pođimo još korak dalje. Ne samo da je prema Augustinu u Gospodinovu učovječenju riječ o milosrđu, a ne o bijedi, ${ }^{47}$ ne samo da, prema Leonu, zbog milosrđa nije bila zatamnjena slava onoga koji se smilovao, ${ }^{48}$ nego obojica rado ističu čudesnost milosrđa očitovana u događaju utjelovljenja, muke i smrti Sina Božjega. Tumačeći u jednom božićnom govoru djevičansko začeće, Augustin veli: »Ta je moć čudesna, ali još je čudesnije milosrđe da se htio roditi onaj koji se mogao tako roditi.« ${ }^{49}$ Leon Veliki će pak reći da od svih djela Božjeg milosrđa nema ničega čudesnijeg i uzvišenijeg od toga da je Krist bio raspet za svijet. ${ }^{50}$ Slično na drugome mjestu, gdje govori o još čudesnijem Božjem milosrđu koje se očituje u tome da Krist nije umro ni za pravednike ni za svete, nego za nepravedne i bezbožne. ${ }^{51}$

Izvrstan primjer u kojem zajedno nalazimo govor o utjelovljenju i smrti Sina Božjega iznosi Augustin u kontekstu korizmenog poticaja kršćanima da uz pomoć Gospodinova milosrđa, svojim milosrđem, postovima i molitvama pobijede mnogobrojne napasti. Ondje se pita: može li biti većega milosrđa prema bijednim ljudima od onoga koje je nagnalo Stvoritelja nebesa da se spusti s nebesa, Stvoritelja zemlje da se obuče u zemaljsku odjeću, onoga koji u vječnosti ostaje jednak Ocu da postane jednak nama u smrtnosti, Gospodara svemira da se zaodjene u obličje sluge tako da on, koji je kruh, može ogladnjeti, koji je sitost ožednjeti, koji je snaga oslabjeti, koji je zdravlje biti ozlijeđen, koji je život umrijeti? Da njegovo pitanje nije slučajno, potvrđuje to što ga još jednom ponavlja, pitajući koje to milosrđe može biti veće od toga da Stvoritelj bude stvo-

netjelesan i uzima tijelo, o istome koji je u sebi nepovredljiv i u našoj slabosti trpljiv, o istome koji se ne odjeljuje od Očeva prijestolja, ali je bio prikovan na drvo, o istome koji je uzašao na nebo, ali nije ostavio Crkvu, o istome koji će doći u tijelu u kojem je uzašao, o istome koji je istobitan s Ocem i pravi čovjek.

${ }^{47}$ Usp. Aurelius AUGUSTINUS, Sermo 192. In Natali Domini, 3, www.augustinus.it/latino/ discorsi/discorso_245_testo.htm (21.07.2017). Premda nije riječ o bijedi, svakako jest o poniznosti, u kojoj se iskazuje veličina Božjeg milosrđa. Usp. Aurelije AUGUSTIN, Ispovijesti, 141: »kako je veliko tvoje milosrđe u kojem si ljudima pokazao put poniznosti, što Riječ tvoja tijelom postade i nastani se među ljudima «.

${ }^{48}$ Usp. Leo MAGNUS, Sermo LXX. De Passione Domini XIX, 3, u: PL, 54, 381-382.

${ }^{49}$ Aurelius AUGUSTINUS, Sermo 192. In Natali Domini, 1, www.augustinus.it/latino/discorsi/ discorso_245_testo.htm (21.07.2017).

${ }^{50}$ Usp. Leo MAGNUS, Sermo LIV. De Passione Domini III, 1, u: PL, 54, 319.

${ }^{51}$ Usp. Leo MAGNUS, Sermo XIL. De Passione Domini VIII, 8, u: PL, 54, 342. Ovdje autor dodaje da se Krist za nas mogao žrtvovati samo zato jer se rodio od nas, jer božansku narav ne može pogoditi žalac smrti. Vidi i Leo MAGNUS, Sermo LXVII. De Passione Domini XVI, 3, u: PL, 54, 370, gdje Leon Veliki veli da Raspeti, koji je došao spasiti grešnike, nije odbio svoje milosrđe ni onima koji su ga ubili, nego je zlo bezbožnika promijenio u dobro vjernika. 
ren, vladar sluga, otkupitelj prodan, uzvišeni ponižen te oživljavatelj ubijen..$^{52}$ Navedene Augustinove misli na jednostavan i slikovit način, koji u sebi nose snagu da se usijeku u srce i misao svakoga slušatelja, posvema su na tragu već spomenutoga otačkog inzistiranja na milosrđu kao sponi koja služi zadržavanju istovjetnosti vječnoga i utjelovljenog Logosa.

Prije negoli se, u zadnjem poglavlju, predanije posvetimo potonjoj temi, istaknimo još nekoliko mjesta iz kojih je razvidno da se u milosrdnom Sinovljevu prihvaćanju ljudske bijede zapravo očituje Božja moć te se, na prvi pogled paradoksalno, milosrđe, koje - kako smo vidjeli - već po definiciji uključuje trpljenje, pa stoga i nemoć, poistovjećuje s najvećom mogućom, Božjom moći. Augustin, zanimljivo, o Sinovljevu uzimanju obličja sluge govori u kontekstu tumačenja riječi da je »moćno milosrđe Gospodina Boga našega.$^{53}$ Gregorije Nisenski pak podsjeća da u mnogim odlomcima Svetoga pisma sveti Božju moć nazivaju imenom »milosrdan.$^{54}$ Njegov brat Bazilije Veliki, nadovezujući se na već citirane riječi u kojima ukazuje na razlikovanje onih imena koja su vlastita Kristovoj božanskoj naravi i onih koja mu nadijevamo zbog njegove milosrdne pomoći upućene čovjeku, upozorava čitatelja da i samo milosrđe iskazano u smrti na križu valja promatrati kao čin koji očituje božansku moć:

»Zar, dakle, takva skrb za nas navodi pamet da o njemu mislimo nisko? Ili, naprotiv, ta skrb ulijeva strahopoštovanje pred velikom Spasiteljevom moći i njegovu čovjekoljublju, jer je pristao da supati s našim slabostima i bude sposoban da se spusti do naše bijede? Jer ni nebo ni zemlja, ni beskraj pučina, ni morske ni kopnene životinje, ni raslinje, ni zvijezde, ni zrak, ni godišnja doba, ni svestrano uređeni svemir ne očituju toliko veličinu njegove moći koliko činjenica da je beskrajni Bog mogao, ne trpeći, po tijelu, vezati se uz smrt da bi nama vlastitom mukom udijelio milost besmrtnosti. ${ }^{55}$

Zaključimo kratkim mislima i ovo poglavlje. Gospodinovi izričaji kojima je $\mathrm{u}$ više navrata iskazao svoju podložnost Ocu nesumnjivo su morali one koji su sudjelovali u rađanju kristologije suočiti s tegobnim nastojanjem da ih razriješe na najbolji mogući način, ne odstupajući od istine da je taj isti, utjelovljeni Sin Božji koji je za nas podnio muku i smrt, istodobno jednak Ocu po božanskoj naravi. Jedan od načina ili, bolje, jedan od putova prema traganju za ispravnim rješenjem, opet jest govor o svim etapama Gospodinova života kao izrazu najčudesnijeg milosrđa u kojem se očituje veličanstvena Božja moć.

\footnotetext{
${ }^{52}$ Usp. Aurelius AUGUSTINUS, Sermo 207. In Quadragesima, 1, www.augustinus.it/latino/ discorsi/discorso_263_testo.htm (21.07.2017).

${ }^{53}$ Usp. Aurelius AUGUSTINUS, Epistola 238, 2.10, www.augustinus.it/latino/lettere/lettera_246_ testo.htm (21.07.2017).

${ }^{54}$ Usp. Gregorius Nyssenus, De beatitudinibus, Oratio V, u: PG, 46, 1250.

${ }^{55}$ Bazilije Veliki, Duh Sveti..., 77-78.
} 


\section{Božje milosrđe i hipostatsko sjedinjenje}

U ovom, posljednjem poglavlju, premda ni u jednom od izvora kojima ćemo se poslužiti ne dolazi sintagma hipostatsko sjedinjenje, ukazujemo na ona mjesta u kojima pronalazimo govor o milosrđu u kontekstu strogo kristoloških tumačenja otajstva utjelovljenja, koja se veoma približavaju onome što je definirano na Kalcedonskom saboru 451. godine, naime onih gdje je riječ o sjedinjenju dviju naravi u jednoj osobi ili hipostazi. Navedimo prvo tekst kalcedonske definicije u kojem je smještena ta dogmatska istina:

»Slijedeći dakle svete oce da se ispovijeda jednim te istim Sinom Gospodin naš Isus Krist, suglasno svi naučavamo (da je) potpun taj isti u božanstvu, i potpun isti u čovještvu, zaista Bog i zaista čovjek, taj isti, iz razumske duše i tijela, istobitan Ocu po (svom) božanstvu i istobitan nama taj isti po (svom) čovještvu, po svemu nama sličan izuzev grijeha, prije vjekova od Oca rođen po (svome) božanstvu, a u posljednje dane taj isti radi nas i radi našega spasenja iz Marije Djevice Bogorodice po (svom) čovještvu, (da se) jedan te isti Krist Sin Gospodin Jedinorođeni u dvjema naravima nesmiješano, nepretvoreno, neodvojeno, neodjeljivo spoznaje, nipošto da bi razlika naravi bila ukinuta (po i) zbog ujedinjenja, nego (tako) da se štoviše sačuvala vlastitost (osobitost) jedne i druge naravi, te da se u jedan prosopon (jednu osobu) i jednu hipostazu sletjela, ne da je u dva prosopona podijeljena ili razdvojena, nego (da je) jedan te isti Sin Jedinorođeni Bog Logos Gospodin Isus Krist. $^{56}$

Prije negoli se usmjerimo središnjoj temi ovoga poglavlja, dobro je uočiti da je i sva dosad obrađena tematika na liniji jasno vidljivoga kalcedonskog naglaska o jednom te istom Sinu Gospodinu našemu Isusu Kristu, kako je imenovan na početku, odnosno jednom te istom Kristu Sinu Gospodinu Jedinorođenom kako je imenovan u sredini ili jednom te istom Sinu Jedinorođenom Bogu Logosu Gospodinu Isusu Kristu, kako je imenovan na kraju definicije. S tim smo se naglaskom, koji se gotovo kao refren ponavlja u svim tezama kalcedonske definicije, susreli i u prikazu otačkoga govora o Božjem milosrđu kao motivu i razlogu utjelovljenja, muke i smrti Sina Božjega i u prikazu utjelovljenja, muke i smrti Sina Božjega kao najčudesnijeg djela i očitovanja moći Božjeg milosrđa. Da ne bismo upali u nepotrebna ponavljanja, a ipak dodatno argumentirali sličnost njihovih izričaja i onih kalcedonske definicije, pokušat ćemo prereći njezin prvi dio tako da ćemo, čuvajući sve njezine bitne elemente, u nju ubaciti najvažnije točke dosadašnjeg izlaganja. Time će i sama definicija, koja je prije svega obilježena statičkom kristologijom, za koju je specifično promatranje Kri-

\footnotetext{
${ }^{56}$ Prijevod kalcedonske definicije preuzimamo od T. J. Šagi-Bunića, koji ga je načinio za potrebe svojih studenata (usp. Filić, Efeška kristološka kontroverzija..., 439). Usp. još dva prijevoda na hrvatski jezik: Teodoret CIRSKI, Izabrani spisi, prev. Marijan Mandac, Split, Služba Božja, 2002, 154-155; Heinrich DENZINGER - Peter HÜNERMANN (ur.), Zbirka sažetaka vjerovanja, definicija i izjava o vjeri i ćudoređu, prev. Ljudevit Plačko, Đakovo, Karitativni fond UPT, 2002, 301-302.
} 
sta kakav je u sebi, zadobiti i soteriološku dimenziju ${ }^{57}$ i to upravo kroz unošenje dinamičkog pojma milosrđa. Evo toga pokušaja:

Oci čijim smo se djelima služili suglasno svi naučavaju da je onaj isti koji je potpun u božanstvu, vječni Očev Logos, zbog svojega smilovanja prema ljudskoj bijedi i zbog svojega slobodnovoljnog milosrđa, a nipošto zbog nužnosti ili prisile, postao potpun u čovještvu, zaista Bog i zaista čovjek, taj isti, iz razumske duše i tijela. Onaj isti koji je istobitan Ocu po božanstvu te kao takav nije podložan nikakvu trpljenju ili promjeni, zadržavajući tu istobitnost postaje istobitan nama taj isti po čovještvu (po svemu nama sličan, izuzev grijeha) te time iskazuje veličinu i moć svojega milosrđa koje seže sve do prihvaćanja svih uvjetovanosti ljudskog života koje su prije svega obilježene trpljenjem, promjenjivošću i smrtnošću. Onaj isti koji je prije vjekova od Oca rođen po božanstvu i koji je oduvijek milosrdno djelovao u korist ljudi, u posljednje se dane, kada je to isto milosrđe poraslo do neslućenih razmjera, taj isti radi nas i radi našega spasenja rodio iz Marije Djevice Bogorodice po čovještvu. Većeg milosrđa od toga nije moguće nigdje pronaći! To je najčudesnije djelo Božjeg milosrđa!

Govor o jednom te istom Bogu Logosu koji je postao čovjekom ili, još bolje, identičnost vječnoga i utjelovljenog Logosa bitna je pretpostavka one dogmatske istine koju tradicija podrazumijeva pod izričajem hipostatsko sjedinjenje $u$ kojem se misli na sjedinjenje dviju naravi u hipostazi ili osobi Logosa, $\mathrm{s}$ time da vlastitosti obiju naravi ostaju očuvane. U kalcedonskoj se definiciji to misli u sljedećoj tvrdnji:

»(da se) jedan te isti Krist Sin Gospodin Jedinorođeni u dvjema naravima nesmiješano, nepretvoreno, neodvojeno, neodjeljivo spoznaje, nipošto da bi razlika naravi bila ukinuta (po i) zbog ujedinjenja, nego (tako) da se štoviše sačuvala vlastitost (osobitost) jedne i druge naravi, te da se u jedan prosopon (jednu osobu) i jednu hipostazu sletjela . $^{58}$

Pogledajmo sada mjesta iz otačkih djela u kojima je govor o milosrđu utkan u sadržaj pojmljen pod sintagmom hipostatsko sjedinjenje. Najviše takvih tekstova opet pronalazimo u govorima Leona Velikog. Jedno od mjesta gdje uočavamo najbliskiju srodnost s netom navedenim dijelom kalcedonske dogmatske definicije zacijelo je njegov božićni govor u kojem uz konstataciju »obje su se naime supstancije sastale $\mathrm{u}$ jednu osobu«, dodaje da je to »otajstvo tolikog milosrđa.$_{.59}$ Pod gotovo istom sintagmom, »otajstvo božanskog milosrđa«, Leon Veliki sažima sve važne kristološke teme: ističe Sinovljevu posvemašnju jednakost s Ocem koja ostaje i nakon što je uzeo našu narav te postao ono što nije bio, naglašava da je pravi Bog i pravi čovjek, koji si je sjedinio našu cjelovitu

\footnotetext{
${ }^{57}$ Jedini trag kristologije »za nas«, tj. soteriologije, $u$ kalcedonskoj se definiciji nalazi u riječima preuzetima iz Nicejskog simbola: »radi nas i našega spasenja«.

${ }^{58}$ Filić, Efeška kristološka kontroverzija..., 439.

${ }^{59}$ Leo MAGNUS, Sermo XXIX. In Nativitate Domini IX, 1, u: PL, 54, 226.
} 
narav, tj. i tijelo i dušu, navodi primjere iz njegova života kojima posvjedočuje njegovu ljudsku i božansku narav te zaključuje da je u obojem jedan Krist. ${ }^{60}$

Rimski biskup jasno govori o jednome Kristu i dvjema naravima, pri čemu ni Logos nije odvojen od čovjeka niti je čovjek odijeljen od Logosa, nego je čitavo otajstvo bilo rasporedba milosrđa i čin smilovanja. ${ }^{61} \mathrm{U}$ ovome se ostvaruje Božje milosrđe pripravljeno prije vjekova: Jedinorođeni Sin Božji udostojao se postati sinom čovječjim te se spašavamo po obojem - po tome što isti, koji je istobitan Ocu, postoji i kao pravi čovjek, po tijelu istobitan majci, ni u čem ne odjeljujući vidljivo od nevidljivog, tjelesno od netjelesnog, trpljivo od netrpljivog, ono što se može dotaknuti od onoga što se ne može dotaknuti, obličje sluge od obličja Božjeg. ${ }^{62}$ Podsjećanjem na Božje milosrđe, čiju veličinu nije moguće protumačiti, Leon zaključuje i tumačenje riječi »Riječ je tijelom postala i prebivala među nama...« (Iv 1, 14) gdje govori o jednom te istom Sinu Božjemu koji je u objema naravima, uzevši naše i ne napuštajući svoje, u čovjeku obnavljajući čovjeka i u sebi ostajući nepromjenljiv jer, kako veli dalje, činjenica da je Riječ postala tijelom ne znači da se Božja narav promijenila u tijelo, nego da je Riječ uzela tijelo u jedinstvo osobe. ${ }^{63}$

I na drugom mjestu, opet ističući da je božanstvo Boga Logosa netrpljivo i nepromjenjivo, ali je zbog ljudskoga spasenja, ne napuštajući svoje, milosrdno uzelo naše, zaključuje o jednome Gospodinu, Sinu Božjemu i - istome - Sinu čovječjem, tj. o jednoj osobi i dvama obličjima u Kristu. ${ }^{64}$ U Leonovim govorima, nadalje, zajedno dolaze spomen milosrda i ono njemu specifično uvjerenje, koje je upravo iz njegova spisa Tomus ad Flavianum preneseno u kalcedonsku definiciju, ${ }^{65}$ naime da su obje naravi sačuvale svoje vlastitosti. U to smo se već mogli uvjeriti na temelju svih dosad navedenih njegovih misli.

Pokažimo još gdje je to izravno izrečeno. Dok o otajstvu Gospodinova rođenja govori kao neizrecivoj naklonosti božanskoga milosrđa - jer se Stvoritelj čovjeka udostojao postati čovjekom - dodaje da dok obje naravi ostaju u svojim vlastitostima, zbog jedinstva sve ono što je Božje nije odijeljeno od onoga što je ljudsko, niti je ono što je ljudsko odvojeno od onoga što je Božje. ${ }^{66}$ Veoma sličan, i kalcedonskoj formuli također blizak izričaj nalazimo i u Augustinovu Pismu Volusijanu u kojem naširoko razlaže čitavu kristologiju i gdje stalno provlači misao da je Logos, po kojem je sve stvoreno, uzeo tijelo od Djevice i postao čovjekom uzevši ljudsku narav, ali ne umanjujući ni u čem vlastitosti svoje božanske naravi, te je prošao svim dobima. Ondje Augustin jasno veli da je Logos,

\footnotetext{
${ }^{60}$ Usp. Leo MAGNUS, Sermo XCVI, 2 u: PL, 54, 467.

${ }^{61}$ Usp. Leo MAGNUS, Sermo LII. De Passione Domini I, 2, u: PL, 54, 314-315.

${ }^{62}$ Usp. Leo MAGNUS, Sermo XXX. In Nativitate Domini X, 6, u: PL, 54, 233-234.

${ }^{63}$ Usp. Leo MAGNUS, Sermo XXVII. In Nativitate Domini VII, 1-3, u: PL, 54, 217-218.

${ }^{64}$ Usp. Leo MAGNUS, Sermo XLVI. De Quadragesima VIII, 1, u: PL, 54, 292.

${ }^{65}$ Usp. Epistula Papae Leonis ad Flavianum ep. Constatinopolitanum de Eutyche, 77-82 (usp. i tablicu u Camelot, Éphèse et Chalcédoine..., 140, gdje je to jasno pokazano).

${ }^{66}$ Usp. Leo MAGNUS, Sermo XXVIII. In Nativitate Domini VIII, 1, u: PL, 54, 222.
} 
posrednik Boga i ljudi koji je sjedinio obje naravi u jedinstvu jedne osobe, to učinio na milosrdan način. ${ }^{67}$

Dakako da i kod Augustina i, nadasve, kod Leona Velikog, koji su se mnogo bavili sržnim temama Kristova otajstva - kako u njemu samom, tako i »za nas « - postoje još mnoga mjesta u kojima obrađuju ono što pripada u sadržaj pojmljen pod izrazom »hipostatsko sjedinjenje«. Mi smo se ovdje hotimice zadržali samo na onim odlomcima u kojima smo, paralelno, pronašli i govor o milosrđu. Budući da su ta mjesta u skladu s njihovim kristološkim naukom iznesenim na drugim mjestima, možemo reći da ona u cjelini odražavaju njihova autentična teološka uvjerenja i, još više, živu vjeru u otajstvo Boga koji je za nas postao čovjekom.

\section{Zaključak}

Na koncu odgovorimo na pitanje postavljeno na početku: Ako, naime, milosrđe u sebi nužno uključuje trpljenje (pa bilo ono samo zbog drugoga i za drugoga!), može li se, dok držimo sigurnim da je netrpljivost jedna od bitnih vlastitosti božanske naravi, o njemu uopće govoriti, kako Kasper potiče, kao o temeljnom Božjem svojstvu i odrednici Božje biti? U odgovoru se, dakako, ograničavamo samo na temu kojom smo se bavili u ovome radu i to bez pretenzije da svoj odgovor smatramo konačnim. Jer, u konačnici, kao uostalom i u ishodnici svih naših teoloških promišljanja, stoji svijest da je riječ o neizmjernom otajstvu koje neizmjerno nadilazi svako čovjekovo nastojanje da ga barem djelomice protumači.

Naše pitanje, moramo primijetiti, zapravo sadrži dva pitanja.

U prvom se pita može li se, dok držimo sigurnim da je netrpljivost jedna od bitnih vlastitosti božanske naravi, o njemu uopće govoriti kao o temeljnom Božjem svojstvu. Budući da je Bog termin koji označuje osobu, a ne božansku narav ili bit, u skladu sa svime dosad izrečenim, na to pitanje bez imalo oklijevanja možemo potvrdno odgovoriti. U osobi Isusa Krista, vječne Riječi Božje koja se utjelovila i postala čovjekom, milosrđe se doista pokazuje kao njezino temeljno svojstvo. Izlažući otački govor o milosrđu kao motivu njezina utjelovljenja i otkupiteljskog trpljenja, mogli smo primijetiti da milosrđe nije prikazano kao tek izvanjski, pridodani motiv, nego kao istinski unutarnji motiv druge božanske osobe koji proizlazi iz njezine pune slobode, iz njezine ljubavi i iz njezine volje koja se smilovala grešnom čovječanstvu. Utjelovljenje i trpljenje - shvaćeno bilo kao slobodnovoljno prihvaćanje svih uvjetovanosti ljudskoga

\footnotetext{
${ }^{67}$ Usp. Aurelius AUGUSTINUS, Epistola 137, 2.6-3.12 (osobito 3.9); www.augustinus.it/latino/ lettere/lettera_138_testo.htm (21.07.2017).
} 
života, bilo kao ono koje se dogodilo u posljednjim ovozemaljskim danima ${ }^{68}$ utjelovljenoga Sina Božjega - najveći su čin milosrđa koji je ostvarila druga božanska osoba, po dobrohotnom Očevu naumu i u snazi Duha Svetoga.

Na drugo je pitanje malo teže odgovoriti. Doista, može li se o milosrđu govoriti kao o temeljnoj odrednici Božje biti, ili naravi, dok još uvijek držimo sigurnim da je netrpljivost jedna od bitnih vlastitosti božanske naravi? I ovdje uočavamo da je u Kasperovu prijedlogu uporabljen osobni termin, Bog. Primijenimo li taj termin na temu našega članka, onda pitanje valja ovako postaviti: Je li milosrđe temeljna odrednica biti ili naravi osobe Isusa Krista, vječne Riječi Božje koja se utjelovila i postala čovjekom? U skladu s iznesenim naukom crkvenih otaca, možemo odgovoriti i potvrdno i negativno.

Krenimo od negativnog odgovora. Ocima je, kako smo vidjeli, iznimno stalo do toga da, dok govore o utjelovljenju, muci i smrti vječnoga Sina Božjega, istodobno sačuvaju neokrnjenom njegovu jednakost s Ocem i nepromijenjenost njegove božanske naravi kojoj je jedna od bitnih oznaka netrpljivost. Budući da milosrđe nužno uključuje trpljenje, ne može se reći da je ono temeljna odrednica Sinovljeve biti ili naravi, ukoliko ga se promatra u njegovim vječnim unutartrinitarnim odnosima. S druge strane, ako se ima u vidu sadržaje koje smo obradili, nadasve u poglavlju o milosrđu i hipostatskom sjedinjenju, očito je da se jednom te istom, osobi vječnog Logosa koji se utjelovio i postao čovjekom, mogu i moraju temeljem tog istog sjedinjenja pripisivati vlastitosti i božanske i ljudske naravi. Utoliko naš odgovor na gornje pitanje, bez imalo straha da smo upali u krivovjerje, može biti i potvrdan.

Smatramo da bi najsretnije rješenje problematike sadržane u navedenim pitanjima bilo dobro tražiti na liniji sintagme Kromacija Akvilejskog prema kojem je »Gospodin milosrđe u osobi« ili »uosobljeno milosrđe « ${ }^{69} \mathrm{U}$ tom se naime izričaju, premda izrečenom mnogo prije proglašenja kalcedonske dogmatske definicije, $\mathrm{s}$ jedne strane nazire trag istine o sjedinjenju dviju naravi u jednoj osobi. S druge pak strane, taj izričaj potiče na razmatranje o Božjem milosrđu, koje za nas postaje uosobljeno u osobi Isusa Krista, i to trajno uosobljeno - ne samo u osobi koja je nekoć hodala ovom zemljom, nego i u proslavljenoj osobi

\footnotetext{
${ }^{68}$ Ovdje naravno ne isključujemo vjeru u trajnu prisutnost proslavljenoga Krista na zemlji nakon njegova uzašašća na nebo.

${ }^{69}$ Navedeno prema: Pontificio consiglio per la promozione della nuova evangelizzazione, $\mathrm{La}$ Misericordia nei Padri della Chiesa..., 111 (do izvora, nažalost, nismo uspjeli doći). Ovdje je zanimljivo barem usput primijetiti da trojica posljednjih papa rado govore o Isusu Kristu na sličan način kao Kromacije. Izdvojimo tek nekoliko primjera. Ivan Pavao II. ističe da Isus Krist »milosrde utjelovljuje i uosobljuje. On je sam, u određenom smislu, milosrde« (DM 2). Joseph Ratzinger, današnji papa emeritus Benedikt XVI., na euharistijskom slavlju prije početka konklava za izbor novoga pape u svojoj je propovijedi kazao da je Isus Krist »božansko milosrđe u osobi « [Missa pro eligendo Romano Pontifice. Omelia del cardinale Joseph Ratzinger, decano del Collegio cardinalizio (18.04.2005), www.vatican.va/gpII/documents/homily-pro-eligendopontifice_20050418_it.html (21.07.2017)]. Na sličnom su tragu i riječi pape Franje s početka njegove Bule najave Izvanrednog jubileja milosrda: »Isus iz Nazareta svojim riječima, svojim djelima i svojom cijelom osobom otkriva Božje milosrđe« (MV 1).
} 
Isusa Krista koja je, kako vjerujemo, s nama u sve dane do svršetka svijeta (usp. Mt 28, 20). Povrh toga, govor o Isusu Kristu kao uosobljenom milosrđu, otačkim kristološkim naglascima govora o Božjem milosrđu daje dodatnu notu za koju je osjetljiv suvremeni čovjek: naglasak na osobi koja nije samo statički - kao u kalcedonskoj dogmatskoj definiciji - nego i dinamički shvaćena - kao ona koja se ostvaruje u međusobnim (milosrdnim) odnosima s drugom osobom. Takav govor, što je osobito važno, otvara i neke nove perspektive međuljudskog milosrđa, no raspravu o tome ostavljamo za drugu prigodu.

\section{Andrea Filić*}

The Christological Emphases in the Discourse on God's Mercy in Reflections of Selected Church Fathers

\section{Summary}

The initial question of this article, inspired by Walter Kasper's statements, is: If mercy, by definition, necessarily includes suffering, can one even talk about it (as Kasper claims) as God's fundamental characteristic and a determinant of God's essence, given our belief that God cannot suffer? This issue is approached in the article in Christological fashion on the basis of reflections of selected Church Fathers in whose works God's mercy is discussed in the context of specifically Christological reflections. The first chapter provides a short overview of God's merciful activity in the whole history of salvation and it is pointed out that the grandest and most splendid act of God's mercy - the incarnation, suffering, and death of Jesus Christ - is closely linked to it. The second chapter demonstrates that for Fathers the word mercy, used in the context of explaining motives and reasons for the incarnation, suffering, and death of the Son of God, was a terminus technicus. The point of using this terminus technicus was to preserve the tension between the truth about the eternal Logos, who cannot suffer, and the fact that this same Logos became, at the end of time, a human being and endured suffering and death on the cross. The third chapter addresses the patristic texts in which the mercy of incarnation, suffering, and death of the Son of God is presented as the most splendid act of God and the grandest manifestation of his mercy. This understanding also rejects any doubt that the Son who suffered might be subordinated to the Father. In the last, fourth chapter entitled »Mercy and Hypostatic Union«, the attention is drawn to those places in patristic writings where mercy is being mentioned within the context of Christological reflections. These reflections follow closely the Chalcedonian dogmatic definitions on one and the same Jesus Christ, the Son

\footnotetext{
* Andrea Filić, PhD, Assist. Prof., Catholic Faculty of Theology, University of Zagreb; Address: Vlaška 38, pp 432, HR-10001 Zagreb, Croatia; E-mail: andrea.filic@zg.t-com.hr.
} 
of God who has two natures conjoined in one person or hypostasis in which both natures preserve their characteristics. The conclusion points out that the initial question can be answered both positively and negatively. If the person of the Son of God is viewed in his inner Trinitarian reality, then one cannot state that mercy is the fundamental characteristic of his being, because this would imply that the Divine nature can suffer. If, on the other hand, he is viewed within the context of the history of salvation, whose pinnacle has been reached through him becoming a human being and his suffering, and if one would add to this the theological claim that the hypostatic union implies the possibility (and necessity) of ascribing characteristics of human nature to the eternal person of the Father's Word, then the answer has to be positive. At the end, the descriptions of Jesus Christ as "mercy in the person " or "personalised mercy" are suggested as the most appropriate for the mystery of mercy revealed in the event of Jesus Christ.

Keywords: mercy, Church Fathers, Christology, soteriology.

(na engl. prev. Nenad Polgar) 